\title{
Corrigendum
}

\section{The British Government, Ernest Shackleton, and the rescue of the Imperial Trans-Antarctic Expedition - CORRIGENDUM}

\author{
Dudeney J. R., J Sheail and D W H Walton, 2014, Polar Record, DOI:10.1017/S0032247414000631
}

In this publication (Dudeney, Sheail \& Walton, 2014) we revealed that the whaling company Compañia Argentina de Pesca (Pesca) had made an offer in early June 1916 to rescue Shackleton's men from Elephant Island using the combination of their ships the SS Undine and the whale catcher Don Ernesto. This offer was made to Reginald Tower, the senior minister at the British Legation in Buenos Aires and it is described in some detail in Dudeney et al. (2014). The paper describes how “Captain Larsen” personally visited Tower to discuss the proposal in early June. Tower's letter in which he reported the offer to the Secretary of State, Sir Edward Grey, did not definitively identify which Captain Larsen it was, from what was an extended family of mariners. We mistakenly assumed that it was Carl Anton Larsen because of the context - he was described by Tower as an "experienced man who knew the locality of Elephant Island" (Tower, 1916). But we now know that Carl Anton Larsen had severed all ties with Pesca in 1914 and was by then farming in Norway (Riffenburgh, 2016, pp. 310-316). However, we were not the first to make this mistake. In early June 1916 both the Swedish newspaper Svenska Dagbladet and the Times of London reported that C. A. Larsen was mounting a rescue mission. To quote from the Times for June 13 1916: "Captain Larsen, a member of the Nordenskjold Antarctic Expedition, is preparing at Punta Arenas another expedition to leave as soon as possible to relieve the members of Sir E. Shackleton's party marooned on Elephant Island". The appearance of this report caused C. A. Larsen to issue a denial, which also appeared in the Times the next day. The latter article went on: "he states that he lived for nine months with an Antarctic crew after shipwreck on Paulet Island, south of Elephant Island, in a stone hut, and, judging by his experience, he believes that Sir E. Shackleton's men will be able to capture sufficient supplies of seals and penguins even without firearms". But Thomas Orde Lees reported that against his advice, Frank Wild did not make any serious effort to build up a stock pile of seals and penguins sufficient to last a winter, so that by the time the men were rescued from Elephant Island their supplies were almost exhausted (see the diary of Orde Lees presented in Thomson, 2003).

So if it wasn't Carl Anton Larsen who made the offer, who was it? The clue is contained in Tower's letter to Sir Edward Grey where he identifies his visitor as the Captain of the Pesca vessel Tijuca. Hart (2001) very helpfully gives a list of ships' captains involved in the whaling industry and he identifies Oluf Emil Larsen as captain of the Tijuca from 1916 to 1918. O. E. Larsen was a younger brother of C. A. Larsen. Based on this evidence we now conclude that it was in all probability Oluf Emil who would have led the rescue. The mission would not therefore have had quite the cachet of being led by the much more celebrated brother, but would still have had a very experienced Captain in command using ships that were much more capable than any that Shackleton actually used.

\section{References}

Dudeney, J. R., Sheail, J., \& Walton, D. W. H. (2014). The British Government, Ernest Shackleton, and the rescue of the Imperial Trans-Antarctic Expedition, Polar Record, 54, 380-392. DOI:10.1017/S0032247414000631

Hart, I.B. (2001). Pesca. The History of Compañia Argentina de Pesca. Salcombe: Aidan Ellis, 508 pp.

Riffenburgh, B. (2016). C.A. Larsen. Explorer, Whaler and Family Man, ed Kløver, G. O., Publ. Fram Museum, Oslo-Norway. ISBN 978-82-8235-080-8

Thomson, J. (2003). Elephant Island and Beyond, The Life and Times of Thomas Orde Lees, Bluntisham Books, Erskine Press, $339 \mathrm{pp}$.

Tower, R. (1916). Letter to the Foreign Office, 6 July 1916. TNA. FO371 General Correspondence, Foreign Office file FO371/2846, America 1916. 